\title{
Grzegorz EMBROS
}

IEiB WFCh UKSW Warszawa

\section{Instrumenty wsparcia edukacji dla zrównoważonego rozwoju}

\section{Wprowadzenie}

Problematyka ochrony środowiska koncentruje się obecnie na takich aspektach jak: ochrona wody, gleby czy powietrza. Często można odnieść wrażenie, że cała problematyka jest sprowadzana (redukowana) wyłącznie do tych aspektów. W związku z tym, ochrona środowiska jest utożsamiana $\mathrm{z}$ ochroną przyrody, czy inżynierią środowiska. Tymczasem ochrona środowiska ma charakter interdyscyplinarny. Ujmuje bardzo szerokie spektrum zagadnień i problemów często wykraczających poza obszar wspomnianych dziedzin. Mówi się, w tym kontekście, o potrzebie ujęcia holistycznego czy systemowego. W takim przypadku można odwołać się do teorii systemów, w której podstawowym elementem jest system wraz $\mathrm{z}$ jego otoczeniem. Pomiędzy systemem, a otoczeniem zachodzą wzajemne relacje (oddziaływania) o charakterze dynamicznym. W otoczeniu systemu mogą znajdować się inne systemy, z którymi system może również oddziaływać. Oddziaływania (sprzężenia) pełnią funkcję integrującą system $\mathrm{z}$ jego otoczeniem lub innymi systemami. Przykładem systemu może być człowiek (społeczeństwo - jako system wielki), a otoczenia - środowisko, w którym ów system funkcjonuje. Ujęcie takie pozwala na uwzględnienie, $\mathrm{w}$ problematyce ochrony środowiska, znaczenia stanu relacji (wzajemnych oddziaływań) występujących pomiędzy systemem (społeczeństwem), a otoczeniem (środowiskiem, w którym system funkcjonuje).

Procesy, związane z rozwojem struktur społecznych we współczesnym świecie, przebiegają w tempie i skali dotąd nie obserwowanej. Rozwijane są technologie o formie i zasięgu funkcjonowania dotąd nie spotykanym. Globalne społeczeństwo informacyjne coraz mniej funkcjonuje w "naturalnym” (czyli nie przekształconym przez człowieka) środowisku. Coraz powszechniej realizuje ono swą aktywność twórczą $\mathrm{w}$ „świecie wirtualnym” generowanym przez nowoczesne środki masowego przekazu (w tym różne przejawy komputeryzacji) ${ }^{1}$. Tym

1 Por. A. Latawiec, Użyteczność systemowego ujęcia świata wirtualnego, w: W kierunku filozofii klasycznej. Inspiracje i kontynuacje, pod red. J. Krokosa, K. Świętorzeckiej, R. Tomanka, Warszawa 2008, ss. $303-312$. 
samym pojawia się nowy rodzaj oddziaływań „nowego świata” systemów informacyjnych na człowieka. Występują w tym kontekście, zarówno pozytywne jak i negatywne, zjawiska o zasięgu lokalnym i globalnym.

Negatywne skutki prowadzą do ujawniania się sytuacji kryzysowych w przestrzeni społeczno-przyrodniczej. Dobrze znane i wykorzystywane dotychczas metody i praktyki ochrony człowieka w jego, odznaczającym się stosunkowo niewielkim stopniem przekształcenia przez technikę, środowisku okazują się nieadekwatne i niewystarczające. Jak pokazuje choćby potoczne doświadczenie, problemy próbuje się rozwiązywać przy pomocy metod i sposobów postępowania, które doprowadziły do powstania tych problemów. W wielu przypadkach uzyskuje się efekty odwrotne do zamierzonych.

Istotną rolę w niwelowaniu przyczyn kryzysu ekologicznego przypisuje się koncepcji zrównoważonego rozwoju. Jest ona główną propozycją praktycznych rozwiązań, mających prowadzić do zażegnania kryzysu w relacjach występujących pomiędzy człowiekiem, a przyrodą.

Ważne miejsce, w podnoszonej problematyce, zajmują kwestie związane $\mathrm{z}$ potrzebą nowego odniesienia do narastających komplikacji w sferze moralnej i etycznej. Postulowana jest, przy tym, konieczność kształtowania „nowej świadomości ekologicznej”, „nowego sposobu myślenia zorientowanego na kwestie ekologiczne". W relacjach człowiek - przyroda akcentowane są aspekty aksjologiczne. Bez odpowiednio prowadzonej edukacji (uwzględniającej wychowanie) niemożliwa wydaje się być praktyczna realizacja postulatów formułowanych w idei zrównoważonego rozwoju.

Problematyka odpowiedniego przebiegu procesu nauczania i wychowania, zajmuje istotne miejsce zarówno w pracach ekofilozofów, bioetyków, autorów podejmujących problematykę rozwoju zrównoważonego, jak i pedagogów. Pojawiające się w sytuacji kryzysowej nowe problemy dotykają w znaczącym stopniu także tej sfery ludzkiej aktywności. Na różnych etapach edukacji mamy do czynienia z niedomaganiami systemu oświaty. Problemy te dotyczą już nie tylko sposobów i metod przekazywania wiedzy, ale przede wszystkim procesu wychowawczego.

Atomizacja nauki skutkuje brakiem umiejętności dostrzegania powiązań pomiędzy wiedzą pochodzącą z nauk przyrodniczych, społecznych czy filozoficznych oraz umiejętności, które pozwalają integrować wiedzę z różnych dziedzin². Natomiast liczne przypadki agresywnych zachowań wychowanków w stosunku do rówieśników i ludzi starszych (w tym nauczycieli) zwracają uwagę na słabość

2 Opinie, dotyczące procesu dydaktycznego, przedstawiane w latach 60-tych ubiegłego wieku przez prof. Mariana Mazura nie tracą (niestety) na aktualności. Por. M. Mazur, O szkole cybernetycznie - integracja nauczania, w: Argumenty, nr 12 (458), rok XI, Warszawa 1967, ss. 1 i 6. Niektóre publikacje tego autora dostępne są na stronie internetowej www.autonom.edu.pl. 
procesu wychowawczego. Jedną z przyczyn takiego stanu rzeczy jest niewykorzystywanie, przez instytucje realizujące program nauczania i wychowania, skutecznych, nowoczesnych narzędzi teoretycznych i praktycznych. Bardzo często obserwujemy działania, mające eliminować negatywne skutki nieprawidłowości, pojawiających się w procesie wychowawczym (np. wprowadzanie monitoringu szkół, pracowników ochrony czy policji). Bardzo rzadko, natomiast, mamy do czynienia z długofalowymi działaniami, mającymi na celu eliminowanie przyczyn zaistniałego stanu rzeczy. Celowe, wobec tego, wydają się wysiłki zmierzające do wypracowania propozycji wyjścia z sytuacji kryzysowej, obecnej w tej dziedzinie. System edukacji potrzebuje nowych metod, teoretycznych i praktycznych, umożliwiających w sytuacji zmian i ryzyka nowe spojrzenie i prawidłowe odniesienie do pojawiających się problemów. Tym bardziej interesujące stają się propozycje wynikające z ujęć cybernetycznych czy systemowych oraz związanych z nimi zastosowań najnowszych technologii informacyjnych. Coraz ważniejszą rolę odgrywają one w procesie kształtowania się współczesnego społeczeństwa informacyjnego.

Jednym z istotnych zadań szkoły współczesnej jest wyposażenie jej podopiecznych w sprawności, umożliwiające właściwą egzystencję w środowisku społecznym. Coraz częściej akcentuje się również, w związku z sytuacją kryzysu ekologicznego, umiejętność kształtowania odpowiednich relacji pomiędzy społeczeństwem, a przyrodą. Coraz większy nacisk kładzie się na zdobywanie kompetencji uczniów w zakresie rozwiązywania problemów i podejmowania decyzji. W kontekście procesów decyzyjnych nie można uniknąć kwestii odpowiedzialności i motywacji.

\section{Edukacja ekologiczna i środowiskowa}

Edukacja ekologiczna koncentruje się na przekazywaniu wiedzy zaczerpniętej z nauk przyrodniczych. Jest nauczaniem ekologii, rozumianej jako nauka przyrodnicza. Konieczność rozwiązywania problemów, przed którymi stanęło społeczeństwo w sytuacji globalnego i totalnego kryzysu ekologicznego wymaga nie tylko nauczania ekologii, ale również potrzebę wprowadzenia nowych odniesień. Niezbędne stało się uwzględnienie, w procesie edukacji ekologicznej, szeroko rozumianej problematyki społecznej. Edukacja ekologiczna, w takiej perspektywie, winna uwzględniać szerokie spektrum problemów. Wynika stąd potrzeba ujęć systemowych implikujących podejście holistyczne czy holograficzne do zmieniającej się rzeczywistości społeczno - przyrodniczej.

$\mathrm{W}$ takiej koncepcji położony został nacisk na kształt i rodzaj relacji pomiędzy człowiekiem, a przyrodą. Interesujące propozycje przedstawione zostały w tym zakresie na gruncie ekofilozofii. Dzięki nim, edukacja ekologiczna wzbogacana jest przez funkcję wyjaśniającą i integrującą płaszczyzny poznawcze. Poprzez 
analizy dotyczące kryzysu ekologicznego, prowadzone na terenie ekofilozofii, zyskuje obraz najbardziej aktualnych problemów. Natomiast w realizacji procesu wychowawczego korzysta, z proponowanych przez ekofilozofię, opracowań problematyki etycznej czy aksjologicznej. Ekofilozofia uczy myślenia, pomaga w kształtowaniu świadomości ekologicznej, jest zdobywaniem mądrości. Istotny jest uniwersalny charakter ekofilozofii, szczególnie, gdy bierze się pod uwagę rozwój globalnego społeczeństwa informacyjnego. Rozważania ekofilozoficzne przyczyniają się do rozwiązywania (teoretycznego i praktycznego) aktualnych problemów, wytyczania kierunków rozwoju i działań na przyszłość3.

Ekofilozofia może i powinna stać się pierwszym narzędziem, wspomagającym prawidłowy przebieg edukacji ekologicznej. Jej rola ujawnia się w płaszczyźnie metateoretycznej, gdy stanowi refleksję nad samym procesem edukacji. Winna również stawać się, w pewnym zakresie zależnym od etapu procesu edukacyjnego, przedmiotem nauczania.

Szerokie ujęcie, związane z ekofilozoficznymi wpływami na edukację ekologiczną, obok problematyki przyrodniczej, obejmuje kwestie społeczne. Wobec tego, bardziej adekwatne wydaje się być określenie „edukacja środowiskowa”. Odzwierciedla bowiem sytuację, w której człowiek funkcjonuje zarówno w środowisku przyrodniczym, jak i społecznym ${ }^{4}$. Edukacja środowiskowa uwzględnia relacje człowieka ze środowiskiem lokalnym (rodzinnym, szkolnym) i globalnym środowiskiem społecznym oraz związki z lokalnym i globalnym środowiskiem przyrodniczym. Jak się wydaje, określenie „edukacja środowiskowa” pełniej oddaje stan obecnych poglądów na proces nauczania i wychowania człowieka, funkcjonującego w społeczeństwie i przyrodzie. Jest ono zgodne z koncepcją ekofilozofii, postulującą potrzebę ujęć systemowych. Zawiera postulat konieczności poszerzenia problematyki nauk przyrodniczych o problematykę społeczną, moralną, filozoficzną itp.

Dzięki temu, edukacja środowiskowa, zyskuje jakościową odmienność w stosunku do edukacji ekologicznej. Programy nauczania realizowane są, w tym przypadku, z uwzględnieniem kontekstu kulturowego danej społeczności. Kontekst kulturowy obejmuje wówczas takie elementy jak: nauka, technika, sztuka czy religia. Ciekawy przykład mogą stanowić materiały edukacyjne przygotowane i opublikowane w pracy zbiorowej pod redakcją Anny Kalinowskiej i Zbigniewa Barcińskiego, zatytułowanej „Łaskotani chrabąszcza wąsami. Po zielonym świe-

3 Por. J. M. DoŁega, Ekofilozofia i jej otulina, w: Rozmaitości ekofilozofii, pod red. A. Skowrońskiego, T. 57, Olecko 2006, ss. 43 - 67.

4 Por. D. Сıсни, Programowanie celów i treści edukacji środowiskowej, w: Edukacja środowiskowa - programy, metody, efekty, Komitet Naukowy przy Prezydium PAN „Człowiek i środowisko”, Zeszyty Naukowe 28, Warszawa 2002, ss. 22 - 29; D. CicHY, Kultura w edukacji środowiskowej, w: Podstawy kultury ekologicznej, Komitet Naukowy przy Prezydium PAN „Człowiek i środowisko”, Zeszyty Naukowe 32, Warszawa 2002, ss. 13 - 18. 
cie z księdzem Janem Twardowskim". Publikacja składa się z bogato ilustrowanej książki, płyty CD oraz poradnika metodycznego dla wychowawców i nauczycieli. W książce, oprócz interesujących tekstów autorstwa A. Kalinowskiej, opisujących stan przyrody we wszystkich miesiącach roku, znajdują się również odpowiednio dobrane wiersze księdza J. Twardowskiego. Ten sam tekst oraz wiersze znajdują się również na $\mathrm{CD}$ w formie ilustrowanego muzyką i odgłosami natury słuchowiska. Poradnik metodyczny zawiera gotowe scenariusze i propozycje zajęć w cyklu rocznym. Uwzględniają one zmienność przyrody, charakterystyczną dla zmian pór roku - „moduł przyrodniczy”, jak również aspekt religijny w formie „modułu katechetycznego" oraz odniesienie do poezji księdza J. Twardowskiego.

\section{Edukacja na rzecz ekorozwoju}

Zasadniczym celem edukacji środowiskowej staje się merytoryczne przygotowanie zarówno młodzieży, jak i dorosłych do realizacji postulatów ekorozwoju. Uwzględnia się przy tym szerokie spektrum zagadnień i postuluje prowadzenie procesów edukacyjnych w różnych płaszczyznach. W edukacji środowiskowej swoje odzwierciedlenie znajdują główne przesłania idei zrównoważonego rozwoju. Należą do nich: zależność i wzajemne uwarunkowania ochrony środowiska, wzrostu ekonomicznego oraz rozwoju człowieka w wymiarze indywidualnym i społecznym. Istotne miejsce w tej problematyce zajmuje konieczność rozpoznania i określenia zasad współistnienia z przyrodą, uznanie jej wartości oraz odpowiedzialności za zachowanie wszelkich form życia na Ziemi. Ważne jest przy tym uwzględnienie zmiany kryteriów oceny postępu i dążenia do dobrobytu oraz zwrócenie uwagi na realizację nie tylko materialnych, ale także duchowych potrzeb człowieka. Dbałość o jakość życia i otoczenia pociąga za sobą konieczność rozwiązywania wielu problemów związanych z urbanizacją, industrializacją, motoryzacją, informatyzacją, nadmierną eksploatacją ekosystemów. Problemy te wiążą się także z potrzebą poszukiwania nowych źródeł energii oraz wdrażania nowych, „przyjaznych” dla środowiska technologii. Również problemy demograficzne, konieczność likwidowania przyczyn i następstw głodu, biedy, przemocy czy bezrobocia wpisują się w obszar omawianej problematyki.

Istotnym zadaniem edukacji środowiskowej jest kształtowanie całościowego obrazu relacji występujących pomiędzy człowiekiem, społeczeństwem i przyrodą. Ukazuje ona zależności człowieka od przyrody. Uczy także odpowiedzialności za zmiany dokonywane w środowisku naturalnym. Tak określone zadania mogą być realizowane, gdy zostaną włączone do całego procesu edukacyjnego oraz, gdy proces ten stanie się nieodłącznym składnikiem polityki informacyjnej, strategii gospodarczej oraz ochrony zdrowia ludności.

„Edukacja ekologiczna staje się ważnym składnikiem edukacji obywatelskiej zmierzającej do rozwijania społeczeństwa rozumnego i akceptującego zasady 
zrównoważonego rozwoju, umiejącego oceniać stan bezpieczeństwa ekologicznego oraz uczestniczącego w procesach decyzyjnych ${ }^{5}$."

\section{Cele i sposoby realizacji procesów edukacyjnych}

Edukacja zorientowana na realizację postulatów zrównoważonego rozwoju winna realizować cele, związane z kształtowaniem pełnej świadomości ekologicznej i myślenia ekologicznego. Należy przy tym uwzględnić wzajemne powiązania kwestii ekonomicznych, społecznych, politycznych i ekologicznych. Ważne jest umożliwienie dostępu do wiedzy i zdobywanie umiejętności niezbędnych do poprawy stanu środowiska. Kolejnym celem jest tworzenie i kształtowanie właściwych postaw, wartości i przekonań jednostek, grup i społeczeństw, uwzględniających troskę o jakość środowiska ${ }^{6}$.

Prezentowane cele mogą zostać zrealizowane w sytuacji, gdy edukacja środowiskowa stanie się jednym z warunków realizacji Polityki Ekologicznej Państwa. Konieczne jest przy tym prowadzenie tej edukacji we wszystkich sferach życia społecznego przy jednoczesnym respektowaniu i wykorzystaniu wartości kulturowych, etycznych czy religijnych. Realizacja celów wymaga zapewnienia dostępu społeczeństw do informacji o stanie środowiska przyrodniczego i edukacji środowiskowej. Potrzebna jest świadomość zmiany konsumpcyjnego modelu społeczeństwa.

Przedstawione propozycje są odzwierciedleniem zarówno polskich uregulowań prawnych, jak również oficjalnych dokumentów państwowych i międzynarodowych. Nie jest naszym celem dokładna analiza tych dokumentów, jednak należy wymienić choćby najważniejsze takie jak:

- Konstytucja Rzeczypospolitej Polskiej (art. 74);

- Polityka Ekologiczna Państwa z maja 1991 r.;

- Druga Polityka Ekologiczna Państwa z czerwca 2000 r. (Rozdz. III. Cele polityki ekologicznej w zakresie jakości środowiska, pkt. 3.7.; Rozdz. IV. Narzędzia i instrumenty polityki ekologicznej, pkt. 4.6. Dostęp do informacji, udział społeczeństwa, edukacja ekologiczna.);

- Narodowa Strategia Edukacji Ekologicznej (2001 r.);

- Agenda 21 (Rozdz. 36, pkt. 36.5. b Promowanie nauczania, kształtowanie świadomości społecznej i szkolenia w zakresie trwałego i zrównoważonego rozwoju i ochrony środowiska);

- Ramowa Konwencja Narodów Zjednoczonych w sprawie zmian klimatu

5 Przez edukację do zrównoważonego rozwoju. Narodowa Strategia Edukacji Ekologicznej, Ministerstwo Środowiska, Warszawa 2001, s. 8.

${ }_{6}$ Por. D. Cichy, Świadomość ekologiczna młodzieży szkolnej, w: Świadomość i edukacja ekologiczna, pod red. J. M. Dołęgi i J. Sandnera, Warszawa 1998, ss. 9 - 27. 
(Art. 6. Edukacja, szkolenie i świadomość społeczna);

- Konwencja o ochronie różnorodności biologicznej (Art. 13. Podnoszenie poziomu wiedzy i świadomości społecznej);

- Międzynarodowa Strategia Edukacji Środowiskowej UNESCO (1990 r.).

Polskie Ministerstwo Edukacji Narodowej i Ministerstwo Ochrony Środowiska, Zasobów Naturalnych i Leśnictwa, realizując zalecenia Agendy 21, podpisały w 1995 roku porozumienie o współpracy w zakresie edukacji ekologicznej. W rezultacie przygotowano Narodową Strategię Edukacji Ekologicznej. Przy udziale przedstawicieli instytucji, organizacji i środowisk zajmujących się edukacją ekologiczną w Polsce oraz ministerstw i urzędów centralnych, szkół wyższych, podstawowych i ponadpodstawowych, organizacji pozarządowych, mediów i władz lokalnych określone zostały zadania, które należy wspólnie zrealizować. Po uwzględnieniu wielu problemów oraz usunięciu mankamentów w opracowanym dokumencie strategii, poddano go konsultacjom społecznym. Strategia została przyjęta przez ministrów Ochrony Środowiska Zasobów Naturalnych i Leśnictwa oraz Edukacji Narodowej w 1997 roku. Rok później była przedmiotem obrad Sejmowej i Senackiej Komisji Ochrony Środowiska, które zaakceptowały treść dokumentu. W związku ze zmianami wynikającymi z wprowadzanych w Polsce reform, w 1999 i 2000 roku uaktualniono treść Strategii.

Strategia Edukacji Ekologicznej to dokument, w którym zidentyfikowane zostały główne cele i priorytety edukacji środowiskowej. Wskazane jednocześnie zostały sposoby oraz podmioty odpowiedzialne za ich realizację. Do podstawowych celów Narodowej Strategii Edukacji Ekologicznej zaliczono:

- Upowszechnianie idei ekorozwoju we wszystkich sferach życia, uwzględniając również pracę i wypoczynek człowieka, czyli objęcie permanentną edukacją ekologiczną wszystkich mieszkańców Rzeczypospolitej Polskiej.

- Wdrożenie edukacji ekologicznej, jako edukacji interdyscyplinarnej, na wszystkich stopniach edukacji formalnej i nieformalnej.

- Tworzenie wojewódzkich, powiatowych i gminnych programów edukacji ekologicznej, stanowiących rozwinięcie Narodowego Programu Edukacji Ekologicznej, a ujmujących propozycje wnoszone przez poszczególne podmioty realizujące projekty edukacyjne dla lokalnej społeczności.

- Promowanie dobrych doświadczeń z zakresu metodyki edukacji ekologicznej.

W Strategii zdefiniowane zostały cele i zadania edukacji ekologicznej w formalnym systemie kształcenia. Uwzględniono w tym przypadku wychowanie przedszkolne, edukację na poziomie szkół podstawowych i ponadpodstawo-

Przez edukację do zrównoważonego rozwoju. Narodowa Strategia Edukacji Ekologicznej, Ministerstwo Środowiska, Warszawa 2001, s. 11. 
wych oraz szkolnictwo wyższe i edukację dorosłych. Ponadto określona została struktura pozaszkolnej edukacji ekologicznej, w której uwzględniono instytucje i urzędy centralne oraz cele edukacji ekologicznej na szczeblu wojewódzkim i samorządowym. W strukturze tej swoje miejsce znalazły: administracja terenów cennych pod względem przyrodniczym, organizatorzy wypoczynku i turystyki oraz organizacje społeczne, Kościoły i Związki Wyznaniowe. Cele edukacji ekologicznej winny być realizowane w miejscu pracy i środkach masowego przekazu. Przewidziano także możliwość realizacji celów edukacji ekologicznej w rodzinie ${ }^{8}$.

Dokument Narodowej Strategii Edukacji Ekologicznej uwzględnia bardzo szeroki zakres zadań, celów i sposobów ich realizacji. Dotyczy nie tylko interdyscyplinarnego charakteru wiedzy będącej przedmiotem nauczania, ale również zmierza do integracji wielu środowisk, mogących zaangażować się w proces edukacyjny i wychowawczy zorientowany ekologicznie. Wielość płaszczyzn i etapów realizacji celów, określonych w Strategii, odzwierciedla systemowe podejście do omawianej problematyki. Ujawnia się ono w propozycjach zintegrowanych działań, uwzględniających problematykę z wielu dziedzin twórczej aktywności człowieka. W nurt ten wpisują się także postulaty mówiące o tym, że przy realizacji celów edukacji ekologicznej istotną rolę pełni bezpośredni kontakt wychowanków z przyrodą. Dzięki niemu możliwe jest zarówno rozbudzanie wrażliwości na piękno przyrody i ład przestrzenny, jak i kształtowanie postawy szacunku dla życia i zdrowia. Zwraca się także uwagę na potrzebę poznawania praw i współzależności rządzących środowiskiem społeczno-przyrodniczym. Ułatwia to kształtowanie umiejętności rozwiązywania problemów i podejmowania decyzji zgodnych z posiadaną wiedzą oraz przyjmowanym systemem wartości ${ }^{9}$.

Holistyczne podejście do podejmowanych, w dokumencie Narodowa Strategia Edukacji Ekologicznej, zagadnień wymaga odpowiednich narzędzi mogących poprawić lub umożliwić realizację postulowanych zadań. Wymienić należy w tym przypadku:

- wiedzę z zakresu nauk przyrodniczych i ekologicznych;

- wiedzę obejmującą zagadnienia polityczne, społeczne czy ekonomiczne;

- filozofię i religię - umożliwiające właściwy przebieg procesu wychowawczego;

- systemy informacyjne.

\footnotetext{
8 Por. Przez edukację do zrównoważonego rozwoju. Narodowa Strategia Edukacji Ekologicznej, Ministerstwo Środowiska, Warszawa 2001, ss. 13 - 21; Edukacja środowiskowa. Agenda 21 realizacja zadań edukacyjnych. Materiały z konferencji 5-7 maja 1997, praca zbiorowa pod red. Danuty Cichy, Warszawa 1997.

9 Por. A. PAPUZı́́sKi, Edukacja ekologiczna jako instrument polityki ekologicznej. (Uwagi na marginesie narodowej strategii edukacji ekologicznej Przez Edukację do Zrównoważonego Rozwoju). w: Polityka ekologiczna III Rzeczypospolitej, pod red. A. Papuzińskiego, Bydgoszcz 2000, ss. $113-132$.
} 
Przykładem realizacji programu edukacji dla zrównoważonego rozwoju, uwzględniającego realizację wspomnianych celów, może być zbiór scenariuszy lekcji opracowanych przez zespół Uniwersyteckiego Centrum Badań nad Środowiskiem Przyrodniczym Uniwersytetu Warszawskiego. Opracowanie to ukazało się w 2002 roku pod tytułem „Internet w edukacji dla zrównoważonego rozwoju". Materiały dostępne są w Internecie oraz w formie książkowej uzupełnionej płytą $\mathrm{CD}^{10}$. Zawierają one szereg propozycji, związanych $\mathrm{z}$ organizacją i przebiegiem zajęć lekcyjnych, obejmujących zakresem prezentację idei zrównoważonego rozwoju, jej cele oraz problemy pojawiające się w tym kontekście. Każdy scenariusz przebiegu lekcji jest dostosowany do sformułowanego problemu, który powinien być rozwiązany w trakcie zajęć, przez pracujących zespołowo uczniów. Jasno i precyzyjnie określone są cele lekcji, zaprezentowane są także środki dydaktyczne, materiały pomocnicze ( $\mathrm{w}$ tym literatura uzupełniająca) oraz adresy zasobów internetowych, z których uczniowie powinni korzystać $\mathrm{w}$ trakcie zajęć. Sposoby ich wykorzystania przedstawione są w precyzyjnym opisie (krok po kroku) dotyczącym przebiegu zajęć. Istotne miejsce, w trakcie rozwiązywania określonego problemu, zajmuje dyskusja inicjowana przez nauczyciela na podstawie pytań, odnoszących się do zdobywanej przez uczniów w trakcie zajęć wiedzy. Zdobywana jest przede wszystkim wiedza merytoryczna. Uwzględniane są także aspekty społeczne czy ekonomiczne. Problemy prezentowane są w szerokim ujęciu charakterystycznym dla odniesień systemowych. Dzięki temu uczniowie mają możliwość zapoznania się z takim typem ujęć. Pytania problemowe, inspirujące dyskusję, winny skłaniać uczniów do własnych przemyśleń i ich prezentacji na forum grupy. Tak realizowany program przyczynia się do wyrabiania umiejętności samodzielnego docierania do informacji istotnej i wartościowej ze względu na możliwość rozwiązywania konkretnych problemów. Uczeń włączany jest tym samym w proces decyzyjny, który towarzyszy rozwiązywaniu problemów. Sprzyja to kształtowaniu twórczej i odpowiedzialnej postawy w stosunku do omawianych zagadnień. Zaangażowanie intelektualne i emocjonalne może przyczyniać się do formowania świadomych postaw oraz aktywnego uczestnictwa w działaniach i projektach realizowanych na rzecz ekorozwoju.

Omawiany program edukacji dla zrównoważonego rozwoju uwzględnia potrzebę korzystania, przez uczniów, z tematycznie dobranych stron internetowych. Na przykład podczas lekcji, na której podejmowana jest problematyka zaangażowania polskich instytucji i organizacji rządowych czy pozarządowych w realizację postulatów zrównoważonego rozwoju, analizowana jest treściowa zawartość ich stron internetowych. Uczniowie zdobywają wówczas praktyczne umiejętności posługiwania się komputerem i odpowiednim oprogramowaniem. Kształtowane

${ }_{10}$ Internet w edukacji dla zrównoważonego rozwoju. Podręcznik dla nauczycieli, Warszawa 2002; zasoby dostępne na stronie: ucbs.geo.uw.edu.pl. 
są przy tym umiejętności poszukiwania, porządkowania i wykorzystywania informacji z różnych źródeł. Umiejętności te pozwalają na efektywne posługiwanie się technologią informacyjną, która może pełnić rolę wspomagającą i wzbogacającą wszechstronny rozwój uczniów.

Interesującym przykładem, rozwoju technologii informacyjnej służącej edukacji dla zrównoważonego rozwoju, może być portal internetowy EkoEdu ${ }^{11}$. Głównym zadaniem portalu jest promowanie idei zrównoważonego rozwoju. Tematyka portalu poświęcona jest w szczególności Dekadzie Edukacji dla Zrównoważonego rozwoju ONZ, koordynowanej przez UNESCO.

Innym, ciekawym przykładem ewaluacji systemów informacyjnych w kierunku zastosowań edukacyjnych może być edukacyjna gra internetowa Carbon Game. Jest to interaktywna symulacja rzeczywistego rynku handlu emisjami. Odzwierciedlone są w niej sesje giełdy, na której dokonywany jest obrót uprawnieniami do emisji. Promuje ona „[...] pozytywne myślenie zmierzające do ograniczenia globalnego ocieplenia poprzez wprowadzenie handlu pozwoleniami na emisję $\mathrm{CO}_{2}$. To skierowany do młodzieży projekt wzmacniający edukację na rzecz zrównoważonego rozwoju"12. Do gry dołączony jest pakiet instrukcji dla nauczyciela, dzięki któremu może on przygotować multimedialne zajęcia. Portal udostępnia także szeroką gamę rozmaitych materiałów mogących stanowić bogate źródło informacji na temat różnych aspektów zrównoważonego rozwoju.

Cele edukacji dla zrównoważonego rozwoju mogą być coraz lepiej i skuteczniej realizowane dzięki wykorzystaniu systemów informacyjnych. Należy jednak podkreślić, że świat wirtualny nie może zastępować świata realnego (bezpośredniego kontaktu człowieka z przyrodą).

\section{Zamiast zakończenia}

Technologia informacyjna odgrywa istotną rolę w procesach dydaktycznych. Wzbogaca sposoby i wspomaga możliwości zdobywania wiedzy i umiejętności praktycznych. Znacząco usprawnia proces uczenia się oraz pełni rolę integrującą różne obszary doświadczenia i wiedzy. Wzbogacona wiedzą merytoryczną z dziedzin takich jak cybernetyka, czy teoria systemów, ułatwia rozwiązywanie problemów i podejmowanie decyzji ${ }^{13}$.

Dzięki technologii informacyjnej możliwe jest całościowe postrzeganie i ujmowanie skomplikowanych zjawisk. Jest ona doskonałym narzędziem wspomagającym twórczą pracę człowieka. Ułatwia poszukiwanie, porządkowanie i wyko-

\footnotetext{
11 Por. EkoEdu, Portal poświęcony Dekadzie dla Zrównoważonego Rozwoju ONZ, koordynowanej przez UNESCO, www.ekoedu.uw.edu.pl, 15.05.2010.

12 Por. Carbon Game, www.carbongame.org, 15.05.2010.

13 Por. M. Mazur, Jaka szkoła?, w: Przegląd Tygodniowy, rok III, nr 22 (113), Warszawa 1984, s. 14.
} 
rzystywanie informacji pochodzących z różnych źródeł. Usprawnia organizację pracy oraz projektowanie działań. Jest to technologia stale rozwijająca się, wymaga zatem stałego uczenia się. Dostarcza środków umożliwiających komunikację, uczy więc sposobów porozumiewania się. Znacząco ułatwia współpracę w grupie, zarówno w skali lokalnej jak i globalnej.

Tak znaczące usprawnienie procesu dydaktycznego poszerza przestrzeń możliwości, związanych ze stosowaniem jej w procesach wychowawczych. Technologia informacyjna staje się nowym typem technologii, która nie tylko przyczynia się do uatrakcyjnienia i usprawnienia procesu nauczania. Jest narzędziem mogącym usprawniać proces kształtowania postaw i wychowania.

\section{The instruments supporting education for sustainable development}

\section{SUMMARY}

The interdisciplinary nature of environmental protection dooms most of the presently applied protection methods to failure. It is particularly vital an issue in present times of an ecological crisis which occurred as an effect of tackling environmental problems solely from a technical point of view. A crucial role in eliminating effects and causes of the crisis plays the idea of sustainable development. Therefore, it is necessary to carry out proper educational activities for practical realization of its demands what may end the ecological crisis. The author of the paper presents currently applied educational methods and consequences of their application. Simultaneously he points out a necessity of a holistic approach to education for sustainable development what might be guaranteed, among others, by ecophilosophy. He also highlights a potential of the information technology in realization of educational activities for sustainable development. 